\title{
3
}

\section{On culture, economy, and demography}

\section{Turkey and Europe}

Turkey's relations with Europe and the EU have covered a multitude of issues, in particular being heavily involved with economic, political, cultural, ethnic, social, religious, secular and excessive national issues, the democratic process and military interventions in that process, human rights, minority rights, immigration and other aspects. Turkish association with Europe was meant to be the epitome of the country's integration in the Western civilization; membership in the relevant economic and military bodies (NATO, the EU), the chief agents to achieve it. Alas, the road to Europe has been hectic, something that often resembled a roller-coaster ride. Savage and bitter criticisms were exchanged, pleasantries and compliments were reciprocally given, rosy and optimistic hopes for better times were shared. Absolute democracy has been the EU prerequisite; insistence that each nation has a right to its own form of democracy and that Turkish democracy should be seen as the equal of any other has been the Turkish view. In this chapter we analyze the major elements of this complex relationship. ${ }^{1}$

\section{Realities, ambivalence, and hopes: Turkey and the EU}

The 1990s started with an explicit wish of the Turkish President to link its country's moves in the Gulf War to a rapprochement with the EU. The Luxembourg decision of December 1997 to reject Turkish accession into the EU rebuffed Turkey's wishes. The Helsinki's decision two years later to offer Turkey a place corroborated it. The 1990s have thus produced a debit and a credit side to Turkey's relations with Europe and the EU.

The Customs Union between Turkey and the EU, which took effect in January 1996, has been a qualitative great leap forward. At the end of the 1990s, 50 percent of Turkey's yearly trade was with the EU, more than 37.5 billion dollar. 
In 1998, for instance, Turkey's imports from the EU reached 24.08 billion dollars, its exports 13.5 billion. $^{2}$

But not all remained plain sailing. The December 1997 EU Luxembourg decision to bypass Ankara and to invite eleven applicant countries to negotiate membership was bitterly perceived in Turkey, as if the Europeans were pushing a strategically significant and loyal colleague away from the West. Ankara regarded the resolution as an unjust, unfair, discriminatory step. Implicitly it put on Turkey the entire onus for the Greco-Cypriot-Kurdish and other minorities' conflicts with Turkey. It was for Turkey to accept her contenders' solutions and not the other way round, hence the pushing of Ankara to the end of the queue. Others were preferred to Turkey, including some who are less advanced, including the Cypriot Greeks. Inviting the Republic of Cyprus while not solving first the Island's ethnic-political problems, and simultaneously excluding the Turkish Cypriots from the negotiations was particularly galling for Turkey, a clear expression of just how little regard or respect Europe had for her.

The resolution came at a bad time for the Turkish government. By 1997, a growing number of Turks no longer identified with the West or defined themselves as Europeans, while Muslim organizations and parties were successfully challenging the country's ruling, Westernized, secular elite - itself beset by several leadership crises - in the street and in the polls. ${ }^{3}$ Prime Minister Mesut Yilmaz defined the Luxembourg decision as an attempt by the EU, Germany in particular, to set up a "New Berlin Wall" in Europe, an effective means to isolate Turkey. It was, Yilmaz thundered, German racism, a desire of creating a "New Lebensraum" on the part of Germany, a pure religious discrimination on behalf of the EU, that was to divide Europe along a line stretching from Christian Bulgaria to Muslim Turkey. German remarks that the Turkish Prime Minister was "running amok," spewing chauvinist rhetoric, were hardly designed to improve Ankara's temper. Much use has been made for instance, with the German Chancellor Helmut Kohl's declaration that Turkey's chances of accession into the EU were slim, because the European boundaries coincided with those of Christendom.

But the tide turned again, and in Turkey's favor, when Greece removed its veto or, as Ankara would have it, "sabotage." (See Chapter 6.) Also, a new Social Democrat-Greens coalition government favorable to Turkish candidacy emerged in Germany in 1998. The coalition projected a more open stand toward EU enlargement, rejecting narrow geographical interpretations and religiouscultural criteria. ${ }^{4}$ Above all, the path seemed easier for a different attitude towards Ankara when the Turkish-PKK war was practically over. By offering Turkey a place the organization does not simultaneously import a violent conflict. The Europeans were also convinced by US lobbying to change policies toward Turkey. A favorable look at Turkey's candidacy would give a boost to the professed EU goal of democratization in that country, argued Washington who added that it would advance "the important role the organization has in promoting values of tolerance and diversity toward the Muslim world." ${ }^{5}$ This all 
culminated in Helsinki's invitation to negotiate Turkey's membership. Still, when one realizes what the EU wants Turkey to change before it is admitted, one also understands that Turkish accession is not close. There still remains the issue of granting social and cultural - perhaps even political - rights to the Kurdish minority. Also, more than 20,000 Turkish laws and regulations must first be amended and improved to conform 90,000 pages of EU requirements and guidelines for legal, political, economic and cultural standards. Small wonder that the reaction of Turkey's Foreign Secretary to these demands was an allegation that "The EU behaves towards us like 'colonial governors."'

The sympathy throughout Europe toward earthquake stricken Turkey in 1999 was wide, even astonishing. The August tremor, measured 7.4 on the Richter scale, was one of the strongest - and longest, at 45 seconds - to hit Europe in recent memory. It shocked Turkey's industrial heartland, southeast of Istanbul, and left 17,000 dead and 30,000 injured. Almost every European country rushed to send Turkey relief aid and the EU Commission allocated monies for humanitarian needs and for building housing for survivors. A two-hour television appeal in Germany raised 7 million dollars, a similar campaign in the Netherlands produced 13 million dollars. ${ }^{7}$ The change in the attitude of human rights groups - which in 1997 opposed Turkish accession but in 1999 favored it - apparently showed that EU candidacy was thought to offer the best hope for a reform in Turkey. Indeed in 1999, shortly after winning the April elections, the government of Turkey's Prime Minister, Bulent Ecevit, launched an anti-torture reform campaign. ${ }^{8}$ Many Europeans, particularly those on the left who are influential in EU governments, feel goodwill toward Ecevit, who is considered to be "clean" when it comes to corruption issues, and who believes in social democrat ideas. Before he entered parliament as an Ankara deputy and becoming a politician (1959), Ecevit has been a pioneer of labor rights in his country. He has also been an English translator who studied art, history, Bengali and Sanskrit at London University. A man of letters, a writer, an editor in Turkey's dailies, and a poet who arouses sympathy, his works had been translated into German, Russian, Romanian, Serbo-Croatian, Danish and Swedish.

Turkey in the 1990s enjoyed the talents and the reputations of two successful leaders - Ozal and Ecevit. (Erbakan's year in office is considered an "accident"; Yimaz's and Ciller's got mixed evaluations). Internally and outside Turkey, the two leaders pursued their country's interests, and in most cases brought fame and success to Turkey. More important, they managed to persuade their constituencies and public opinion, as well as foreign governments and world media, of the justification of Turkey's policies. It is not very often one comes across a decade in which two successful politicians like Ozal and Ecevit lead Turkey.

Even Kurdish organizations softened when the idea of removing the ban on Kurdish-language television and broadcasts was given a boost following the announcement of the December 1999 Helsinki decision. (In August 2002, the Turkish Parliament finally approved these concessions.) The thesis that 
advocates cooperation with Turkey - not alienation - as a means of extricating concessions from it, apparently proved itself. Ismail Cem, Turkey's Foreign Secretary, defined the ban as an obstacle to Turkey's EU membership. A bit earlier, in one of Turkey's leading newspaper, in an article entitled "Turkey vs. the West," the writer openly advocated the opening of a Kurdish television channel in Turkey. Who cares if the Kurdish Turks will have their own station? Could this possibly harm anyone, he asked. He even went a step further and offered Kurdish, Arabic, Uzbek, Turkish and Ottoman Turkish as electives in high schools. If an ethnic language television channel abuses its position and preaches armed uprising or insults, the station should be taken to court and fined severely. "If they lost enough money enough times, they would be careful henceforth or they would go broke... This is a Western concept, and not necessarily always a good thing, but it works: make them pay money!"9 Enabling the Kurds in Turkey to live their own culture in line with their traditions and customs has caused the Turkish State Minister Responsible for Human Rights to approve the teaching of the Kurdish language. "But I do not think that there is a need to learn Kurdish math [or] Kurdish biology," he commented. ${ }^{10}$

Kurds are not allowed to use their language in education, but the ban on Kurdish broadcasts is largely ignored. No official legal action has been taken against dozens of newly opened local radio stations broadcasting in Kurdish. But not everyone in Turkey was entirely happy with even these moderate advances in Turkey's Kurdish policies. President Demirel observed that there were several Kurdish dialects. Suppose Turkey allows broadcasts in the Kurdish language, what accent should be used? Could Turkey afford to allow all of them on air? And if the Kurds are allowed to have their radio, should Turkey give the same to the Georgians, to the Arabs? According to the Turkish constitution, schools may teach only the official languages of recognized states. As there is no Kurdish state, Kurdish cannot be taught, concluded the President. ${ }^{11}$

Major hurdles still make Turkey's accession into the EU a long and protracted one. Though the reasons seem to be more cultural and emotional with strong relevance to human rights (see Chapter 5), and not strictly economic, deep gaps still exist in the latter area as well. For instance, EU inflation for the years 1998-2000 has been 1.3-1.7 percent annually. Alas, the Turkish average figure was close to 70 percent, and the crisis of winter 2001 elevated inflation even further. The average increase of EU exports and imports for the same period comes to 7.1-6.7, and 7.0-6.2 percent, respectively. The Turkish average figures amount to minus 5.4-minus 12.5, and plus 2.7-minus 3.6. ${ }^{12}$ Another disturbing economic gap is Turkey's budget deficit, which has soared to 14 percent, whereas the EU permits its members a shortfall of no more than 3 percent. Hence, the cost of economic adjustment and support programs to bring Turkey closer to EU levels would be prohibitively high. Eighteen years after admitting Greece, the EU still pays assistance to this country. Do we need a second Greece, officials ask in Brussels. Kenneth Moss mentions that some Europeans also fear the strengthening of the "Mediterranean Voice" in EU bodies, and worry lest 
Turkey's cheaper cost of labor, when combined with its strong work ethic, would draw jobs out of northern Europe. But, above all, it seems as if the inclusion of a Muslim state, partly Asian - "whether Turkey is really Byzantium in a fancy dress" - is hardest for the Europeans to swallow..$^{13}$

The inclusion of millions of Turkish farmers threatens to break the EU budget. In a typical expression, an EU official commented desperately of the "butter mountains" that will be doubled if Turkey is in the EU, as are the farming subsidies the EU presently grants -43 billion dollar a year. If the Turks join the 7.13 million EU farmers - 4.3 percent of the EU workforce as against 43 percent in Turkey - and agriculture is expected to double, then subsidies will double as well, or come to astronomical sums if given per person. The fact that, at present, Turkey's agricultural exports to the EU rarely exceed 17 percent (and is mere 5 percent in imports), fails to allay EU anxieties. On the contrary, it convinces the Europeans that trade with Turkey would show a negative balance, for the Turks' purchasing power is one-third the EU average ${ }^{14}$

Similarly threatening is the migration of millions of industrious Turks who would move in to take the jobs of Europeans. There remains the issue of human and minority rights, and the abolition of Article 312 of the Turkish penal code - that practically accuses anyone who dares to criticize the state with violating the law against preaching hatred. Disputed aspects of Turkish democracy also mar relations, for instance, the issue of political freedoms, the role of the military in politics, etc. "It's a bit tricky counting on Turkey's top brass: they feel committed to defend their country's democracy - as they perceive it - secularism and westernization. That is why they rush to intervene in domestic politics whenever they smell that the three or each of them are under assault" - is a typical NATO attempt to understand the Turkish internal realities. ${ }^{15}$

We have already mentioned that more than 20,000 Turkish laws and regulations must be amended and improved to conform to EU requirements. True, Ankara tries hard and does strive to change its laws. Among the 502 new articles of the new penal code, one finds the abolition of the death penalty, the elevation of the minimal age eligible for prison punishment to twelve years old, preaching hatred and separation was redefined, its scope greatly limited, etc. Still, the Turkish parliament is known for its dilatory methods when controversial new laws are debated. The proposed new penal code might therefore experience changes that will practically emasculate the above amendments.

The EU also takes a negative position vis-à-vis Turkey's periodic forays into northern Iraq in its war against PKK, and as a result the EU is holding up the dispatch of military supplies. In Germany, for instance, the dispatch of bridgebuilding equipment was frozen, so was a grant of 150 million DM for the construction in Germany of two destroyers for the Turkish navy. Norway recalled military supplies already on their way to Turkey.

These hurdles notwithstanding, Prime Minister Ecevit saw no hindrance to Turkey being ready in less than four years for full membership, i.e. by 2004 . Cem, the Foreign Secretary, more cautious and realistic, expected it to happen 
in fifteen years' time. ${ }^{16}$ However, skepticism prevails in Turkey. Turks were not overjoyed when hearing about Helsinki but have remained fundamentally unconvinced of the Europeans' willingness to accept them as one of their own. The embrace, they said, could be capricious and short-lived. It was mentioned that Helsinki is hardly the first time the Europeans have recognized Turkey's Europeanness. In 1856, the Ottoman Empire was invited to join the Concert of Europe. More than a century later, following the signing of the Association Agreement between the European Economic Community and Turkey (1964), Turkey was solemnly declared as being part of Europe. Such flattering remarks have been uttered many times during the past 200 years, mentions Dov Waxman, yet Turkey's European identity has never been settled. On the contrary: Ankara is often reminded that its human rights record, its military's interventions in politics, its rampant, unruly, and unchecked corruption, its poor market economy, and its conflicts with the Hellenic world do not leave much room for hope regarding Turkey's possible accession into the EU. ${ }^{17}$

\section{Turkish immigrants in Germany}

Next to Greece, Germany has been the strongest opponent of Turkish membership in the EU, allegedly because it fears the inundation of the country with more Turkish immigrants, in addition to the 2.8 million already there - the largest migrant group in Germany. More than 1 million Turkish workers are employed in EU countries, of which 700,000 reside in Germany. Germany has some 8 million foreigners - just under 10 percent of the population. "Ethnic Germans" from the former Soviet Union - who, incidentally, speak no German - raise the ratio to 13 percent. Although Germany stopped accepting foreign workers after the 1973 energy crisis and the ensuing increases in oil prices, it still absorbs, annually, 100,000 "Ethnic Germans," 60,000 relatives of foreigners already residing in the country, and 100,000 refugees. Refugees and asylum seekers in Germany - the country has long been a prime destination for asylum seekers amount to 1.7 million. Between 1990 and 2001, almost 2.05 million people applied for asylum in the country - about 41 percent of the overall number of applicants in Western Europe. Ten percent were eventually granted shelter. ${ }^{18}$ Half a million of the 2.8 million Turks living in Germany are of Kurdish origin. A Turkish-Kurdish conflict is, thus, very viable in Germany. Turks are the largest group among the 3.2 million Muslims residing in Germany. For comparison, there are more than 5 million Muslims in France, 2 million in Great Britain, and one million in Italy - altogether there are 12 million Muslims in the EU. Islam, as a result, has become the second largest religion in Europe. It has a strong Turkish character in Germany, a more Indian-Pakistani character in England, and a more Magrebian character in France, where close to 2 million Moroccans and Algerians live. ${ }^{19}$ Following the civil war in Yugoslavia, some 1.4 million immigrants have migrated to EU countries, the majority to Germany, where 280,000 
Muslim immigrants from Bosnia-Herzegovina look for help and shelter. Berlin is, or is close to being, the third largest Turkish city in the world, after Istanbul and Ankara. In addition, the 51,000 Turkish entrepreneurs comprise the largest group (18.3 percent) among foreign entrepreneurs in Germany, whose number at the end of the 1990s reached 279,000. There are also 23,000 Turkish university students and 48,000 vocational training (apprentices) students. ${ }^{20}$

German citizenship has been granted only to a fraction of the Turkish immigrants - 160,000. The main argument against a dual Turkish-German citizenship is that holding two passports produces "half a citizen" of a doubtful loyalty. However, a change - some say a revolution because hitherto citizenship was granted according to that of the parents, not place of birth - took place in 1999 in the German naturalization law. From now on it enables the granting of a German passport to children of immigrants born in Germany, living and integrating continuously there for fifteen years, i.e. citizenship according to the Land Law, or Jus Soli, not blood affinity of the parents. These children would be able to keep their parents' nationality, but would have to choose one at the age of twenty-three. Only in rare hardship cases will adults be allowed to hold two passports.

In general, Germans associate the word "Islam" with Turks who, owing to their numbers, are more visible than other Muslims. Islam and immigrants from Muslim countries -Turkey inclusive - are almost automatically associated by many Europeans with memories of wars with the Ottoman Empire, but also with religious fundamentalism and extreme political ideologies. The fact that many immigrants come from ex-European imperial colonies adds to the uneasiness that exists in the meeting of former masters and formers natives. A perceptive summation was given lately by Roger Cohen of the New York Times: the ghost that hovers now above Europe is not anymore communism but the foreigner and his or her otherness. Similarly, Professor Faruk Sen, director of the Turkish Research Institute in Essen, Germany, asserts that Muslim immigration to Europe, or Islam in Germany, are perceived today by the majority of Germans as a hindrance to integration, as a menace, as a symbol of alienation, and as something which threatens to dilute their "Europeaness." The consequent demand that the immigrant should adopt German (or European) culture and drop the ethnic or national microcosom he or she has established in the receiving countries, is a sure recipe for a conflict. Immigrants to Europe nowadays mean a problem, not a potential, not a possible positive contribution, not a solution to the growing European demand for more people. ${ }^{21}$

Introversion and extremism are therefore the results. The exclusion and discriminatory steps taken by the European majority, are reinforced by inward moves and isolation - even ghettoization - taken by the migrant minority. The gap is accentuated and widened in particular for the young ones. In Germany half the Turks are below the age of thirty. They have lost any affiliation with their parents' countries of origin but find no welcoming attitude in their places of residence, although 61 percent of the Turks living in Germany were born there 
or have resided there for more than twenty years. When Turkey and Germany are excluded, Islam remains the option of identity of these young Turks: ${ }^{22}$

Most third generation Turks in Germany do not have a sufficient knowledge of German even though most of them have been born and raised there. Outside work or school they have little reason to speak German. They tend to live in urban enclaves with extensive Turkish networks of shops, restaurants, mosques and professional services. They can even watch Turkish TV ... available via cable or satellite ... For many young Turks, inability to communicate effectively in the language of their adopted country is a real handicap. It often means poor scholastic achievement and inferior education. In 1998, only 14 percent of Turkish secondary school students qualified for university admission, compared to more than 30 percent of their German counterparts ... With unskilled jobs becoming ever scarcer, unemployment among those untrained Turkish youths is more than twice the national [Germany's] average of 9.6 percent. This leads to growing frustration among the youngsters and makes them more susceptible to political and religious extremism ... [In such circumstances] fundamentalist Islamic organizations and nationalist Turkish associations [thrive]. ${ }^{23}$

No wonder, concluded The Economist, that the chances of these migrant young Muslims and Turks being unemployed, suffering from poor education, and being molested and abused by the local police, are much higher than those of the same indigenous, non-migrant group age. ${ }^{24}$

The difficulties linked to the reunification of the two German states, and the increase in unemployment - 17 percent without jobs in what was before East Germany, 3.7 million unemployed people in the entire country - produce strong xenophobic emotions, racism, vicious and brutal attacks against foreigners residing in Germany. There were 16,000 cases of racist incidents in Germany in the year $2000-1,000$ of them violent - a dramatic increase of 59 percent by comparison with 1999. Turks, not surprisingly, were made particular scapegoats for the social turbulence in Germany. ${ }^{25}$

Some scholars speak of two Turkish communities in Germany: the integrated minority, and the community enclosed within its own world. Only the minority among the Turks in Germany communicates in German, in fact even the third generation faces difficulties in freely speaking the language. The rest - the majority - speaks only Turkish, eats Turkish food, listens to Turkish music, and watches Turkish television. They actually "live at the borderline with Germans and not in an integrated way." In short, they have created their own isolated worlds within German towns, trying not to integrate with the German society. More than a little uneasy, Germans have compared their Turkish community unfavorably to the Haitians, who emigrated to the United States and made every effort to raise their children as Americans in order to ensure their future. ${ }^{26}$

These migrant workers, Turks included, demand of their hosts services that are equal but segregated, their culture forbidding believers to mingle with infidels. They have no desire to assimilate, nor do they wish to adopt the social and political models of Europe's secular society. "They are subjects of Allah, not the 
state." Extremist voices among them even argue that "You are more Muslim when you are against the West." No wonder the European majority blames them for rejecting freedom of speech and full democracy. Furthermore, what Europeans perceive as repression of women in the migrants' Muslim society, and issues of forced arranged marriages, abortion and sexuality, often leads to conflict with the institutions of the host country. Preservation of family honor through the murder of women is not a matter the host country can delegate to internal family jurisdiction. The civil wars in the Balkans are also perceived as interfaith conflicts, injecting the specter of religious war into the already sullied atmosphere. Even if Europeans do not wish to show indifference to the massacre of Chechens or Bosnians or the people of Kosovo in the former Yugoslavia, the relatives of the victims, along with the Muslim states, complain that because the victims were Muslim Europe did nothing to save them. ${ }^{27}$

Cultural disdain for Turks is part of European fear of a Muslim influx that would alter the character of Europe's population. The migrants reaching Europe from North Africa and Indonesia, the Indian subcontinent and Turkey, are all Muslims. As already noted, more than 3 million Turks reside in EU countries. In Britain and France, Muslims constitute over 10 percent of the population. At the end of the twentieth century, some 20 million Europeans identified themselves as Muslims. Continued immigration, negative population growth in some West European countries, and a high rate of natural increase among the migrants, fan European fears that within a generation the ratio of Muslims in the population of Western Europe will reach 25 percent. The migrants' inclination to stay aloof, and the local population's reluctance to enter into anything but the most essential contacts with them, combine to create a separate Muslim culture in Western Europe. Convinced that their culture is superior to that of their infidel host countries, the migrants do everything possible to preserve their customs and heritage. Alternatively, they have grave reservations about European calls for them to assimilate themselves in the cultures of the host countries. Experiencing violent racist reactions, Muslim migrants to Germany quote the fate of German Jews whose integration did not spare them extermination. "Next time there are gas chambers in Europe they will be for Muslims." ${ }^{28}$

Islam in Germany - as associated with Turks, above - has become even more "visible," through the increase in the proportion of women among migrants because the religious affiliation of women is clearly and publicly manifested in their attire, particularly in their veils. A survey in Le Monde, for example, revealed that an ever growing number of Muslim women in Britain had adopted the hijab, the traditional Islamic head covering. Germany is no different. During the years many Turkish families followed their men and migrated to Germany. This family reunification confronted the German society - or other European receiving state - with the cultural and social consequences of migration that had thus far been neglected: schools, kindergartens, proper housing, health services and clinics, intra-family abuse, etc. No wonder legal restrictions and economic incentives like direct payments for those who return to their countries of origin, as well as 
assistance in establishing new businesses there - were imposed and offered by the German authorities. The aim in Germany was decreasing the number of Turks residing there and limiting the number of those who would be potential candidates for naturalization and for German citizenship. ${ }^{29}$

The EU attracts immigrants, many of whom are Turks, many of whom come to Germany. More than 1.2 million immigrants came to Germany in 1992 - Turkish job seekers, ethnic Germans, refugees of the Yugoslav upheavals and of the collapse of communism in east Europe. In 1997 the number was down to 615,000 . The explanation for this attraction is that side by side with its economic prosperity, the EU population, Germany's included, is becoming older. By 2025 the percentage of those above the age of sixty-five will be 22.4 percent - compared with 15.4 percent in the year 2000 - and the number of children born to EU women is declining. On average, when a woman gives birth to an average 2.1 children the number of people in a given place remains stable. However, in EU countries women give birth to an average 1.45 children, with German women even fewer - 1.3. Natural population growth in the entire EU (in 1999) was 270,000, which is less than one-thousandth of the 380 millions who live in EU countries. Legal immigration for the same period -there must have been many more illegal immigrants - amounted to 711,000, almost three times the EU natural growth. ${ }^{30}$ Young foreigners in growing numbers are the work force who fills the gaps, replacing the aging Europeans and those who look for "clean" jobs only, and allocate from their wages the monies needed to sustain the growing numbers of retired people.

Half of Germany's population, which will decrease and number 66 million in 2050 ( 82 million in 2000), will be over sixty years old. Already one in six Germans - 17 percent - is above the age of sixty-five, and children comprise less than a quarter of the population. What is happening in Germany applies to the rest of the EU. There are many European countries among the twenty countries worldwide with the lowest birth rate. "In 17 European countries there are more burials than birthday parties, more coffins are being built than cradles." ${ }^{\prime 1}$ The rapid urbanization that the continent has experienced since the Second World War is one of the explanations for the shrinking numbers in EU countries. The size of urban accommodation is less than in rural areas, hence less space is left for children. Women need to look for jobs outside the home to help sustain their families. The family and the church are a diminishing influence. Abortions and family planning are available. There is increasing use of contraceptives, an increase in the number of one-parent families and a growing demand for higher educated women - women who develop their own careers and thus delay parenting. It is said of Italy that by the year 2010 it will be the "first culture in history" in which the number of people of sixty years old or more will be higher than the age group for birth to eighteen and, more apocalyptically, if perhaps fancifully, "900 years from now and there will be no more Italians." 32

The situation in Germany is not much better. The country is aging, average life expectancy is seventy-six years, but the number of the working, active 
people, whose tax payments sustain the country's welfare system is rapidly diminishing. Already the major share of the national budget -36 percent - goes to the Ministry for Welfare and National Insurance. Within a generation the German pension system will hardly be able to cope with the growing class of retirees whose share in the population will increase from 22 to 40 percent. Currently, for every four workers who are active in Germany, one is retired and enjoys the pension system. Before long, with the growing number of pensioners, that ratio will be down to just two:one. The country, thus, is in a great need of immigrant workers. Eventually it will have to absorb them as citizens, and will benefit from their work and tax payments.

Immigrants to Germany are young - which is understandable - but they might constitute a demographic and cultural threat. Twenty percent of the foreigners residing in Germany are between the ages of birth and twenty-four; for Germans the equivalent figure is 13 percent. Fifty-one percent of foreigners are in the age group of twenty-five to fifty-four, which is the main workforce; for Germans it is 41 percent. The picture reverses in the age group of fifty-five to sixty-five, and older: here there are many more Germans - 16.5 percent - but only 4.5 percent foreigners. German politicians try hard by offering German women more money - 484 dollar a month - to increase births and to raise the fertility rate to 2.2 children per woman.

Between the years 2000 and 2050 Germany will have to import 487,000600,000 foreign workers annually to keep its workforce stable, France 109,000, and the entire EU - 1.6 million. Without immigration, Germany's working-age population will drop from 41 million now to a mere 27.3 million in 2050. To sustain the mid-twenty-first century pension levels in EU countries, the working and taxpayer groups among the number of Europeans will have to increase by another 75 million. Many of them will be immigrants. Yet, as migration expert Han Entzinger concludes, although "markets need migrants, the people don't want them"33

It will not be a wild guess to assume that there will be many Turks among the foreign workers who seek jobs in the EU. Similarly, one can assume that racism will increase, among other reasons, because of allegations that Turks hold jobs of unemployed Europeans (10-11 percent EU average), that foreigners abuse the European welfare system, etc. All this brings to the fore the fears among Germans from growing Turkish immigration. It also sharpens, particularly German, sensitive issues related to citizenship, kinship, blood-affinity, ethnicity, etc.

\section{Turkey-EU: hectic negotiations}

Turkey's Gulf War profit-loss balance will not be complete without taking into account the post-war relations between Ankara and the EU. President Ozal's support for the anti-Iraqi coalition stemmed, inter alia, from an eagerness to gain the sympathy of the EU, perhaps boosting Turkey's chances of admission to it. In 
March 1995 Turkey reached agreement with the EU on a customs union, coming into effect on 1 January 1996 - the highest affiliation stage short of membership. Tansu Ciller, Prime Minister at the time, regarded the agreement as virtual membership in the organization, perceiving its outcome as irrevocably rooting Turkey in the West. ${ }^{34}$ In December 1999 Turkey was invited by the EU Helsinki meeting to negotiate its accession into the organization. It is almost forty years since Turkey concluded its first agreement with the European Community, when it signed (1963) an association agreement. In 1987 Ankara submitted a request to become a member of the EU. But accession is not a foregone conclusion: the hurdles are many, and the changes that are demanded of Turkey are tough. The agreement reached in March 1995 is in practice Turkey's highest achievement, and will probably remain so for many years to come.

The customs union was a significant step forward in Turkey's relations with the EU. The initial results were a 5 billion dollar increase in Turkey's trade deficit with the EU, bringing the total deficit to 10 billion dollars. (Usually, Ankara attributes these deficits to Greek blockage, or "sabotage," of EU funds due to Turkey to improve its competitiveness). Yet the wave of bankruptcies predicted by many never came to pass. The EU did foresee Turkish difficulties and established the "Customs Union Package," a financial aid to Turkey of 375 million ecus for the years 1996-99, plus access to other EU funds, all totaling 2.5 billion dollars. The money was supposed to help the Turkish economy by tackling the implications of the customs union. Accordingly, some 7,000 Turkish businesses, which owing to removal of customs faced cheaper EU products, were assisted by the package. Monies were also granted for the adoption of effective and cheaper production techniques, or for a total shift aiming at the production of entirely new goods. ${ }^{35}$

Turkey's policy during the Gulf War may have helped the Europeans to overcome various inhibitions and objections, and to sign the customs agreement. A Greek veto, it should be recalled, was removed by the EU promise to start admission negotiations with the Republic of Cyprus. Turkey is also perceived as an island of relative stability in the heart of regional ferment, extending from the Balkans to Central Asia. But opposition to Turkey continues. Accepting new members, in addition to the fifteen countries that currently compose the EU, raises questions as to the character of this organization. Some favor a larger body, even of twenty-seven members, a move that will prevent the further deepening of the current federal frame and will help preserve the unique features of each member. Others favor a smaller body but with greater unity. No doubt Turkey has better chances with the first school of thought. Still, the grounds for rejecting Turkey relate more to features found in it and less to the wider discussion about the future of the EU.

Inflation, denial of human rights, repression of the Kurds, the lack of social security mechanisms, and the large size of the country's agricultural sector these are the common arguments to exclude Turkey. In the 1980s the EU maintained that the gap between its poorest member - at that time Portugal - and 
Turkey is still significant: Turkey's GNP was then only one-third that of Portugal. Greece, not Portugal, is nowadays at the bottom of the EU ladder. Still the gap is clear when the 1999 figures are surveyed: 11,739 dollars GDP per capita in Greece, 3,159 dollars in Turkey. ${ }^{36}$ Thus, Turks are constantly reminded that their per capita annual income is well below the EU average, and much less than the organization's poorest. When 43 percent of Turkey's population are peasants, an agriculture nightmare to the EU as well as a cultural gap, because "peasants make for tough cops," then rejecting Turkey is a double-edged sword. It is cashing in on human rights issues and raising objections on economic grounds.

The size of Turkey's population and its deviation from the conventions prevalent in the EU, alarm the organization. Should Turkey join, it would soon be the EU's most populous member, with all that that means as regards representation in the European Parliament and in the Council of Ministers. Population predictions pertaining to Turkey are of 70 million by the year 2020, and between 95 million and 98 million by the mid-twenty-first century. By then Germany's population, now 82 million and the EU's largest member, will number 66 million. Thirty-one percent of Turks are under fifteen, as against 19 percent for Europe. Just 6 percent are older than sixty-four, as against 14 percent and climbing in Europe. Similarly, Turkey's area of 300,870 square miles is larger than that of any EU country. Turkish numbers, thus, look threatening, and the EU faces a worrisome situation - a view expressed by a German official but prevalent among other members as well. Should Turkey join, it will be the largest recipient of EU subsidies for members with lower per capita income, the largest number of votes will go to the EU poorest member, to the country which geographically is on the margin of Europe, and to the one that was not among the founders of the EU and has no history of integration in Europe. ${ }^{37}$ The rejection of Turkey, whether on economic, social or cultural grounds, is thus near to total. Some of the EU countries mention that they spent centuries trying to force the Turks and their ilk out of Europe. Are they to be allowed back in? ${ }^{38}$

In general, a population growth of 2 percent means the doubling of population every thirty-six years, hence another piece of worrying evidence for the Europeans. Peace and modern medicine have caused the Turkish population to increase fivefold in the past seventy-five years, from 12 million to more than 65 million today ( 56 million in 1990). Half of Turkey's population is under the age of thirty. Life expectancy that was not much above forty years in the 1930s has increased to seventy-three on average today. The 1940 annual population growth surpassed 5 percent, which then placed Turkey near the top of world demographic lists. It was only after 1980 that the population growth was showing smaller numbers. Family planning and birth control were introduced and abortions were made legal. The process of urbanization has turned out to be a major cause - urban women give birth to fewer children. The population of urban areas reached 56.3 percent by the end of 1990 and 66 percent in the year 2000 - even 71 percent according to another account - compared with only 16.4 percent in 1927. Turkish women looking for jobs outside the home inevitably 
pushed for smaller families. All these factors helped curb Turkey's population growth. The country should be complemented for its current population growth -1.67 percent; thirty years ago it peaked at 2.8 percent. Hopes were expressed (by President Demirel, for instance) that it should be further scaled down to 1.0-1.5 percent. Also, the average number of children born per woman has shrunk from about 7.0 in the early 1930s to 2.7 in 1993 . Thus, readiness to curb excessive national growth, even to de-legitimize it, does exist in Turkey. "A population that increases by more than a million each year can't handle the new crowd. Even if the country's [economic] growth rate is more than 5 percent, [then] finding jobs, providing education, and many other services can't be sufficient," is but one example. ${ }^{39}$

Turkish workers currently resident in Europe, mostly rural, traditionally characterized Anatolian Muslim peasants, are commonly depicted as resisting integration into their host countries, thus preserving and bringing Anatolia into the heart of Europe. As already mentioned, hostility to otherness focuses on the Turks, who are among Europe's largest groups of migrant workers - more than 3 million in EU countries, comprising 24 percent of all migrants workers.

Europeans also fear that religious and cultural divisions "will entail dilution of our European character." European disdain, disagreements and criticism visà-vis the Muslim immigrants, revolve now around issues like the need to separate between state and church, family and women rights, etc. Turkish immigrant girls attending European schools while wearing headscarf, or their participation in coeducational sports and class outings, have become bones of contention. In France, for instance, schoolgirls have been expelled for wearing the hijab. Surprisingly, in Austria the Turkish schoolgirls prefer the Austrian education system: they are allowed to cover their heads, whereas in Turkey this is forbidden by law. (For the headscarf controversy in Turkey, see Chapter 4.) Other disagreements and conflicts relate to the state demand that religious classes at school should be given in German, to the religious services extended to Turkish migrants resident in Western Europe, and so on. The five time a day practice of praying which is seen as a disturbance at the workplace, and the religious slaughtering of animals for the supply of meat that contradicts the laws against cruelty to animals, all serve to further exacerbate existing conflicts. So does Ankara's dispatch of Muslim clergymen to the Turkish diaspora in Europe, the height of mosques' minarets in comparison to church towers - in Germany alone there are 1,500 mosques, only a few have a minaret - and the call for prayers which allegedly disturbs the neighbors. Muslim burial practices in Germany continue to bother the authorities. The Germans would like to restore to themselves for development purposes urban areas that were allocated in the past to cemeteries for Muslim immigrants. However, Muslim law which forbids disturbing burials, is thus contrary to German law which limits "standard burial" to a period of fifteen years.

It seems that unlike that of their Christian neighbors, the religious faith of Europe's Muslims is getting stronger, that of the Turks in Germany included. 
People from Muslim backgrounds are praying more, attending mosques more often, and observing the Ramadan fast more assiduously than they did before when they arrived in Europe or even in their home countries. Living in a foreign world could be the explanation that creates proximity around Islam but accentuates the difference with the secular majority or with the Christian neighborhood. But Time's Nicholas Le Quesne also found that living in Europe gives the Muslim migrants the confidence to practice their religion more openly, relying on the principles of democracy, the rule of law, and the freedoms of expression and association. Unlike their parents or grandparents who thought their sojourn in Europe was temporary and so were content to express their faith in private, their children see Europe as their home and see no reason not to worship more publicly. ${ }^{40}$

As mentioned above, Europeans are disturbed by the Turkish-Kurdish conflict. There can be no doubt that hair-raising testimonies regarding repression of the Kurds - authentic or fabricated - weaken Turkey's advocates. Yasar Kemal, a left-wing writer, the most widely read author in Turkey (Memed My Hawk, Legend Ararat, Song of a Thousand Bulls, and Annotation Trilogy), and a fierce critic of Ankara's policies towards the Kurds, accused the authorities of forcing Kurdish prisoners to eat human faeces. His charges shocked the European Council, which used the harshest of terms to express its acute disgust, and ordered Turkey to pay 500,000 French francs in compensation to its Kurdish victims. Similarly, the European Court of Human Rights condemned and fined Turkey (November 1997) and ordered her to pay compensation, for arbitrarily detaining six former Kurdish members of parliament (MP) in 1994. The MPs were held in police custody accused of separatism and undermining Turkish territorial integrity. The Strasbourg-based court defined the detention a breach of Ankara's commitments to respecting the judicial control of detention under the European Rights Convention, saying authorities could not have a free hand to hold suspects even in terrorism investigations. It added that Turkey could not justify the arrests with the state of emergency prevailing in the country's southeast, because the MPs were arrested for what they said in Ankara. ${ }^{41}$ Birsan Isenderoglu, in the Turkish Daily News, advised Ankara to pursue a different line:

The government spends a lot of its energy reacting to happenings that it envisions as threatening to its image. For example, the Turkish image was not damaged by Yasar Kemal's anti-Turkish article, which was probably read by only a few leftists and communists, until the Turkish government decided to prosecute him. It was then that the story made the headlines in the international press. Turkey neatly fell into the trap. This kind of government reaction strengthens the position of the West and gives it the initiative. It is also a waste of national energy to be overly anxious about what the West thinks. ${ }^{42}$

It is clear that the EU is not anxious to open up its ranks to a violent ethnic struggle of unforeseeable consequences. The Turkish-Kurdish struggle, which 
has been exported to European capitals by the Kurds as a way of drawing world attention to their plight, further reinforces European reluctance to forge new links with the Turks. Conversely, the Helsinki decision to negotiate Turkey's accession came only after the Turkish-PKK war was practically over. It should be noted that many of the Turkish migrant workers in Western Europe are Kurds who make strenuous efforts to ensure that their cause is not struck off the European agenda. Loud Kurdish protests brought about the resignation of Gerhardt Stoltenberg, Germany's Defense Minister (March 1993) when it emerged that, in defiance of a ban by the German parliament, fifteen Leopard tanks had been shipped to the Turkish army, and may have served in repressing Kurds.

Turkey is making efforts to refurbish its cultural and political image in European eyes. The country's image in Europe is not flattering: the films Midnight Express and Lawrence of Arabia, and Turkey's role - real, fictitious, or carried to excess - in the massacres of Armenians, Kurds and Greeks, and Cypriots in twentieth century, further exacerbate hostility. On occasion, Turkey formulated its foreign policy with one eye on Europe. During the Nagorno-Karabakh conflict, between Muslim Azerbaijan and Christian Armenia (see Chapter 4), Turkey remained on the sidelines, offering the beleaguered Azeris little more than token support. Suleiman Demirel, Turkey's President, defended the decision, by explaining that to intervene in the dispute would reawaken the age-old Muslim-Christian conflict, with Muslim Turkey cast as the villain of the piece. "All our contacts with Europe would be disrupted," he claimed. ${ }^{43}$

Efforts have been made to improve Turkey's freedom of expression and association. The media has been reformed - some of the alterations in accordance with the standards of Western democracies - by abrogating the monopoly of state radio and television. In place of one public television channel there are now sixteen, with 300 local stations. The ban on the private use of the Kurdish language was abrogated early in 1991. In theory, Marxists no longer suffer persecution and workers have been given the right to organize. True, the last two reforms were ignored in remote places or in the southeast of the country. Still, in the major urban centers changes do take place. In the spring of 1992, Turkey invited a delegation from the Council of Europe Judicial Committee to tour the Kurdish areas of Anatolia. In April that year, Turkey proclaimed a number of reforms relating to the rights of people detained by the police. Their rights are read to them at the time of arrest. Bureaucratic procedures in criminal trials have been speeded up. There is now a maximum period of two years' detention before trial and a strict ban on torture during interrogations. Accused persons are entitled to legal defense from the beginning of the interrogation phase and evidence elicited by violence or threats is inadmissible in court. Recently Turkey has re-examined its anti-terrorism law, particularly clause 8 , which forbids expressing support for separatist or subversive activity. If clause 8 is one day cancelled, it will enable the Kurds to openly proclaim their views a possibility that has drawn vigorous protests from the Turkish General Staff and right-wing parties. 
It is generally felt that Europe's vilification of Turkey strengthens the Muslim and nationalist elements in the country and reinforces the position that it is unwise for Turkey to look to the West for its future. The sharp rise of the Muslim Welfare party in the December 1995 elections - the party was dissolved by the courts in 1997 but substituted by the Party of Virtue, also to be outlawed by the judicial system in June 2001 (see Chapter 4) - was commonly ascribed to the hostility revealed by the West, Europe in particular, towards the government of Tansu Ciller. Similarly, the surprising rise of Devlet Bahceli's Nationalist Action Party (MHP) in the elections of April 1999 was also attributed to the patriotic feelings many Turks had felt following the crackdown on the PKK and the capture of its leader Abdullah Ocalan. ${ }^{44}$

As earlier pointed out, much of Europe's criticism of Turkey centers on the question of human rights and military interventions in political and democratic processes. Henry Barkey mentions that the very existence of the powerful National Security Council, through which the military exerts its influence over the Turkish politics, is perceived by the EU as a violation of its norms ${ }^{45}$ Another issue that has intermittently risen in the 1990s - epitomized in the resolution of the French National Assembly of May 1998 - is the criticism on Ankara for its refusal to take responsibility for the massacre of the Armenians during the First World War. The subject deeply mars Turkey's relations with other countries. It brings about bitter allegations about European, American and Western hidden aims at the territorial integrity of the country. The Sevres syndrome is repeatedly confirmed whenever the Armenian or Kurdish issues arise.

The Turkish reaction against the French National Assembly's move was harsh. Ankara alleged that the French deputies acted to placate their constituencies - France has one of the largest Armenian communities in Europe, about 300,000 strong, most are descendents of First World War survivors. It blamed the French government for showing indifference and passivity towards the anti-Turkish moves in the Assembly, and the deputies for relying on distorted information. Ankara warned that the decision put Turkish diplomats in peril - the Turkish diplomatic community has suffered thirty-one deaths at the hands of Armenian terrorists since the 1970s. "When we look back on our history there can be certain events that we will not endorse utterly, but today's issue is based on wrong information and is being exaggerated," protested Foreign Minister Ismail Cem. Many in Turkey unequivocally argue that the wrongdoings of the Ottoman Empire have nothing to do with today's Republican Turkey. Further more: "France would also have to explain past conduct in its colonies as well as the atrocities committed more recently by the French Army in Algeria, before saddling modern Turkey with the shame imposed by this bill ... Turks did not commit this horrible crime they are accused of." ${ }^{36}$

As it sees itself receding from hopes for membership in the EU, Turkey has turned to alternatives: relations with Russia, the Ukraine, Israel and the increase of trade with the United States. With the latter Turkey has reached a 6.5 billion dollar trade volume (2001). It has acquired forty-nine American-made Boeing 
737-800 commercial passenger planes (at a cost of 2.5 billion dollars), thus turning its back on the European alternative - the Airbus. It has also called off a 145 million dollar purchase of Eryx anti-tank missiles with France. Turkey concluded a gas deal with Russia (13.5 billion dollars), and plans the further development of its economy based on Russian-supplied energy. However, the ambivalence prevails: among the Mediterranean countries Turkey is the largest commercial partner of the EU. In 1995, for instance, Turkey imported 13.4 billion ecus worth of goods from the EU - an increase of 44.7 percent compared with 1994 - and exported to the EU 9.24 billion ecus worth - an increase of 17 percent compared with $1994 .{ }^{47}$

Some argue that Turgut Ozal overreached himself. He loved to repeat to his audience that just as Turkey's participation in the Korean War gained it admission into NATO, its policy in the Gulf crisis would earn its accession into the EU. He was wrong. Furthermore, the customs union signed with Ankara is not a membership; it is questionable whether one will eventually lead to the other. But to the frustration of Turkey - even bitter allegations pertaining to double and discriminatory standards - there were candidate states that were spared the customs union stage and elevated directly towards full membership. A few others did move rather quickly from one stage to the next. ${ }^{48}$ Atila Eralp's summation is an accurate description of the conflicting views: "While the EU viewed the customs union as a mechanism to improve its relationship with Turkey without linking it to the issue of full membership, the Turkish side viewed customs union as part of a tacit comprehensive package that would eventually lead to full membership." ${ }^{49}$

Helsinki has not changed the feelings in Turkey that Europe does not want to see the Turks in the EU. This emphasizes emotions that the "world is against us," and repeatedly feeds bitter accusations of the application of double standards where Turkey is concerned. The most recent occurrence is the inclusion, in 2002, of the PKK on the EU list of terror groups. The Spanish ETA and the Irish IRA were long ago on the list; so why did the EU waited eighteen years, since 1984, when the PKK had started terror, complained the Hurriyet? It further alleged that though the PKK is on the list, yet if a PKK member asked for a political asylum, say in Germany, this would be granted. This, because Europe differentiates between the organization, which is a terrorist group, and its members, who are entitled to protection. Would the same happen with an ETA or an IRA member, asks the Hurriyet? ? $^{50}$

All this pushes Turkey further away from Europe, towards introversion and inwardness, if not national and religious radicalism. Other options that harbor danger to Turkey's Westernization and declared secularism, are the resumption of too close contacts with the Central Asian republics, or with the sixty or so countries-strong Muslim world. These alternatives are injurious to Turkey, as well as to the Europeans. Both sides should do their utmost not to see Turkey become a party to the Western-Muslim confrontation that erupted in 2001. There should be other options available an answer to these detrimental developments. If Turkey's admission into the EU does not materialize, it could still be 
given access to certain economic, political and military bodies of the EU, whose activity and decisions are of direct relevance to Turkey. This is because, in the final analysis, Europe is Turkey's hope for the twenty-first century, Turkey's markets are important to the Europeans, and its stability and its affinity with the Western democratic world is even more important.

\section{The Turkish economy: a mass of contradictions}

Turkey has responded to the EU's and international financial bodies' charges and demands in a variety of ways. Particular attention was given to the economy, but changes were observed also as regards human rights and foreign policy. There has been a considerable progress in Turkey's economy - in several areas European standards were attained. In several others there were hopes that Turkey would be on a par with the newly industrialized countries (NICs) together with Hong Kong, Singapore, South Korea and Taiwan. There were years in which Turkey appeared on a list of ten countries denoted by the United States as "newly emerging markets" (NEMs). Nonetheless, neither the NICs nor the NEMs can any longer be considered economic "tigers." Economically, the 1990s have badly affected the economies of these countries - Turkey included - and slowed them down by 15-20 percent on average.

The 1998 world economic slump - the collapse of the stock markets in southeast Asia, the spiral of inflation and deep devaluation of the national currencies in places like Russia, Malaysia and Indonesia, the practical bankruptcy of the economies there and debt repayments which stopped, the stagnation in South Korea and the recession in Taiwan - all seem to herald bad news. For Turkish traders and construction firms it meant losing between 7 and 10 billion dollars worth of investment in Russia. (By the end of 1997, the value of contracted work undertaken by Turkish firms in Russia totaled over 12.3 billion dollars. $)^{51}$ As a result, Turkey's public deficit - 7.7 percent in 1998 - jumped in 1999 to 12 percent. Similarly, the ongoing slowdown in European manufacturing which started at the end of the 1990s (the German economy might not show any growth in the year 2001) some of it related to the decrease in US imports of European products, have resulted in considerable European cuts pertaining to Turkish goods.

Detailed figures for Turkey are no different from the above. Of every TL10 of taxes collected in 1999 by the state, TL6.8 had to go into payment of interest accrued on domestic debts. Similarly, the GNP growth was only 1.8 percent, as against the government's modest 2.3 percent estimate. ${ }^{52}$ The decline of the Russian "suitcase economy" brought about a sharp recession in Turkey. As of the late 1980s when communism collapsed in eastern Europe, and with the dissolution of the Soviet Union in 1991, east Europeans and traders from the Commonwealth of Independent States (CIS) started to fill their luggage with Turkish goods and sold these later in their own countries. This Turkish export was estimated at 5.8 
billion dollars in 1997. It decreased, however, to 3.7 billion dollars in 1998. By way of comparison, in 1990 the bilateral Turkish-Soviet trade was 1.8 billion dollars; in 1998 it was 9.7 billion dollars, or 12.7 percent of Ankara's foreign trade. William Hale noted that following the luggage trade exports to the CIS, Russia began to rival Germany as Turkey's biggest export market, buying about 4.1 billion dollars of Turkish goods in 1998, compared with 5.4 billion for Germany. ${ }^{53} \mathrm{~A}$ 30 percent plunge was noted, mainly in the Turkish textile industry, but also in electronics, leather, footwear, and house hold goods, all heavily dependent on the trade with Russia. Istanbul's Laleli market declined from a 0.8 billion dollar volume in 1996, to 340 million in 1997. All in all some 17,000 Turkish companies experienced severe difficulties or, even, went out of business. ${ }^{54}$

The "suitcase economy" has been Turkey's unofficial export to Russia and the driving force behind Turkey's annual 8 percent growth rates between 1995 and 1997. With the eruption of the crisis in Russia (August 1998), and when the numbers of Russian tourist traders visiting the country dropped off, Turkey's growth dramatically plunged. Accordingly, Russia's share of Turkey's official exports fell in 1999 to a mere 2.3 percent. This was 6.9 percent in 1998, or 1.35 billion dollars. One result of the Russian crisis was that foreign fund managers lumped Turkey together with other emerging markets. They withdrew their investments from emerging markets and invested in safe, but low-interest earning US governments bonds. As the crisis in Russia unfolded, panicky institutional investors withdrew around 7 billion dollars of investment shares from the Istanbul Stock Exchange (IMKB), and from government bonds and treasury bills. Share prices on the IMKB dropped as much as 60 percent. Since then the index has recovered, but in term of US dollars, it is still down by 15 percent on the 1998 index, mainly because of the lack of foreign funds in the markets. Another fallout from the Russian crisis was that Turkish bank borrowing costs in international markets have risen by 30 percent. ${ }^{55}$

Russia, however, is not the entire story. In all, the years 1996-99 gave mixed results and implications as regards Turkey's economy. On major items and indicators there were considerable decreases that meant recession. In 1997, for instance, Turkish exports to the EU amounted to 5.72 billion dollars. Earlier, in 1996, it was 12.08 billion. Turkish imports from the EU, for the year 1997, amounted to 11.17 billion dollars; in 1996 it was 21.9 billion. And while decrease of imports signals a healthy situation, in Turkey's case it meant a slowdown in Turkish industry, which imports unfinished goods and commodities, turns them into finished goods, and re-exports them. One should also bear in mind the heavy share of Turkish-EU trade: Turkey's exports to the EU (1999) consist of 53.7 percent of the country's total export. In the same year, 52.7 percent of Turkey's imports originated in the EU. ${ }^{56}$

Some facts and figures concerning Turkey's imports and exports will help explain the changes and fluctuations in the country's economy and foreign trade. At the end of the 1990s Turkey's imports by country groups amounted to: 52.7 percent from the EU, 4.6 percent from the Middle East, and 9 percent from 
the CIS. Exports by country groups were 53.7 percent to the EU, 8.3 percent to the Middle East, and 5.6 percent to the CIS. Germany topped the list of countries from where Turkey imports its goods. Yet, the decline of imported German goods between 1998 and 1999 - from 6.2 billion dollars to 4.8 billion, a reduction of 24.1 percent - clearly point to the economic recession Turkey has experienced. The same picture shows a decline of imports from Italy (from 3.6 billion dollars in 1998 to 2.6 billion in 1999, a 28.8 percent decline), from the United States (a 27.9 percent decline, from 3.6 billion dollars to 2.6 billion), from the UK (from 2.3 billion dollars to 1.8 billion, a 23.5 percent decline), and from Japan (from 1.8 billion dollars to 1.2 billion, a 34.7 percent decline). Altogether, Turkey's imports in 1998 amounted to close on 39 billion dollars; in 1999 it declined to 32.5 billion, a 16.5 percent decline.

The export balance shows slightly better results. It is indicative of the strength of the major trend in the Turkish economy in the 1990s, namely, the increase of the export sector. The huge gap that existed between Turkish exports and imports was dramatically cut. In 1996, for instance, Turkey's exports amounted to 23 billion dollars, imports were 43 billion. Figures for 1999 show 21 billion dollars of exports and 32 billion dollars of imports. This points to the viability of the export trade in the Turkish economy. Alas, it is also a sign of an economic recession, exemplified by the reduction of imports. ${ }^{57}$

The grand total of Turkey's exports in 1998 was 22.48 billion dollars. In 1999 it was 21.4 billion dollars, a 5.7 percent decline. Distribution by countries shows a sharp decline in Turkish exports to the Russian Federation - from 1.32 billion dollars in 1998 to less than 0.5 billion in 1999, a decrease of 62.5 percent. In 1998 Turkey exported goods worth 4.56 billion dollars to Germany; in 1999 this declined to 4.45 billion, a 4.9 percent reduction. Also of importance is the increase in Turkish exports to the United States: 1.93 billion dollar in 1998, and 2.2 billion dollars in 1999, a 4.1 percent increase. Similar results were experienced with Turkish exports to the UK: 1.43 billion dollars in 1998, 1.5 billion in 1999, a 2.3 percent increase. To Israel - ninth among the ten top buyers of Turkish goods - Turkey exported (in 1998) 405 million dollars worth of goods. In 1999 this amount passed 0.5 billion dollars, an increase of 16.8 percent.

Overall, Turkey's economy is a strange combination of enormous successes and huge failures. The country keeps swinging back and forth between prosperity and recession. Success, prosperity, inflation, stagnation and recession - a most peculiar mixture hardly explainable by experts and academics characterize the economy in the past decade. "Economists scratch their heads over how Turkey sustained what the textbooks declared unsustainable - longterm chronic inflation," writes Andrew Finkel in Time. ${ }^{58}$ Asaf Savas Akat mentions that Turkey is the only middle-income and sizeable open economy with relatively developed market structures that has managed to sustain average annual inflation rates around 60 percent for a long period of time without falling into hyperinflation or successfully reducing inflation to reasonable levels. ${ }^{59}$ Together with Japan and Brazil, the World Bank rated Turkey, with 
its 4.3 percent growth rate during the 1965-98 period, as the seventh fastest growing economy among thirty countries. In this period Turkey's gross national product rose from 50 billion dollars to more than 200 billion dollars. The economy thus quadrupled. A striking trend in these years was that Turkey's industrial growth was not limited to the Istanbul and Marmara regions but new centers emerged in inner Anatolia. Nicknamed the "Anatolian Tigers," the industry thrived in Denizli, Urfa, Gaziantep, Konya, and in may other places. Indeed, the country's business seemed to be business, as Andrew Mango writes. $^{60}$ Still, though production quadrupled, income per person only doubled - from 1,590 dollars to 3,160 dollars - owing to a rapid population increase.

In 1995-97 Turkey enjoyed a 7-8 percent economic growth rate. The trade volume for 1998 was 72.8 billion dollars; it had been 1.5 billion dollars in 1970 . In 1994 Turkey exported goods worth 18 billion dollars; in 1999 this was 22 billion. ${ }^{61}$ At the end of the 1990 s the country seemed to have weathered the global crisis well: although in 1998 the growth rate decreased in comparison with previous years, its economy grew 3.8 percent in real terms. In the same year Turkey's GNP increased by 6.33 percent, rising from 192.4 billion dollars in 1997 to 204.59 billion. The country's GDP rose by 5.55 percent, from 188.75 billion dollars in 1997, to 192.23 billion in 1998, and per capita income rose from 3,080 dollar to 3,224 dollars. Yet, again, although the GNP increased in 1998 by 6.33 percent, the per capita income increased by only 4.68 percent because of a 1.58 percent population increase. ${ }^{62}$

Comparatively Turkey's economy did well in the past twenty years. As above, the country more than tripled its per capita income - from 1,000 dollars to 3,220 dollars - surpassing neighbors it previously tailed, such as Syria, Iraq, Iran, and Russia. This was accomplished despite inflation that rarely dipped below 70 percent, an achievement that defied conventional economic wisdom. In spite of inflation - to overcome this its businesses frequently calculate future prices and costs in US dollars, then convert back into TL at the current exchange rate at the time of payment - Turkey's growth in 1998 was much higher than, say, that of South-Korea, or Japan, which have borne the brunt of the Asian economic crisis. Its unemployment rate is low, 5.8 percent - the expectation for 2001 being 6.9 percent - half that of France, Germany and Italy, and close to that of Japan and the United States that stand on 3 and 4.5 percent, respectively. Its 203.8 billion dollar GNP (in 2000) makes Turkey the eighteenth largest economy in the world. In that year the country dropped down one level owing to a 6.4 percent decline in GNP, attributed to the devastating earthquakes and to the aforementioned crisis in Russia.

Turkey topped the list of Europe's fastest growing market for credit cards. In 1999, Istanbul's stock exchange grew faster, in dollar terms, than any other market in the world. Turkey is one of the largest dispensers of foreign aid relative to its GNP, where it was once a recipient. On average, Turkey has a 22 billion dollar foreign currency balance and its industrial output rose more than 10 
percent between 1996 and 1997. The country ranks among the world's top ten producers of iron and steel - producing 13 million ton annually. According to Purchasing Power Parities Turkey holds seventeenth place but, based on US values, Turkey's 200.5 billion dollar income is in fact worth 419 billion, and the 3,000 dollar income per capita is equal to 5,500-6,000 dollars. ${ }^{63}$

Privatization reduced the role of the government in the economy from 50 to 25 percent. Unfortunately, the process was indefinitely postponed in late 1998, waiting to be continued by strong coalition governments. Turkey's huge public sector deficits emphasize the urgency in expediting the privatization process. Usually, successive Turkish governments covered the deficits by printing money or borrowing at sky-high interest rates. Indeed, 50 percent of the country's budget is allocated to cover the public debt. In 2000, privatization restarted and was expected to produce 7.6 billion dollars. A 20 percent stake in Turk Telecom - the twelfth largest communication company in the world worth a few billion dollars, was at risk. However, foreign buyers failed to show up for such a small package so it was removed from the list for privatization. Strong objections, from military echelons in particular, blocked the sale to foreigners of more than 39 percent of any governmental company, Turk Telecom and the national carrier, Turkish-Airlines, in particular, apparently in accordance with the articles of the Turkish law. ${ }^{64}$

"Foreigners will again be our masters," is the Turkish battle cry that resists the privatization demand of the International Monetary Fund (IMF). In this mood, whoever complies with the IMF's conditions, like Kemal Dervis, Turkey's Secretary for the Treasury since February 2001 (he resigned in August 2002), is at risk of being labeled a "foreign agent." Indeed, the IMF and the World Bank made expediting privatization a condition of granting a large and very much needed loan to Turkey. From 1999 through to 2001, the IMF allocated Turkey 19 billion dollars; during the period 2002 to 2004 Turkey would borrow another 16.3 billion, thus becoming the IMF's largest borrower. Eventually, the two financial bodies would give Turkey a financial support of 24.7 billion dollar. Accordingly, they further insisted on cutting public spending as a proportion of GNP by 2.5 percent, and the liquidation of state-owned banks and government involvement in the private banking system. ${ }^{65}$ Turkey's state-owned banks serve the political machine, writing off debts as political favors, with staggering accumulated losses - 20 billion dollars for the two largest banks. Since the end of 2000 the government has directly controled twelve insolvent banks where the Bank of Turkey overseeing system "failed" to discover their imminent bankruptcy and collapse, mainly due to widespread corruption.

The IMF also insisted on the liberalization of the tobacco business, another market that is heavily controlled by the government, and on cutting subsidies to the farms that grow it and supply 600,000 jobs. General reduction of subsidies, decentralization and privatization of the country's energy market and power stations as well as privatization of Turk Telecom and the sale of 51 percent of Turkish Airlines, were but a few of the other demands of the IMF. 
One can easily trace, in the Turkish objection to the IMF's stipulations on privatization and sale of government assets to foreigners, the fear of a recurrence of the ill-famed Ottoman capitulation system. The word in Turkey was not a call for painful changes and catharses but for the rejection of the IMF's "dictate." ${ }^{\prime 6}$ The Sevres syndrome exists also in Turkey's economy: foreigners just look for the occasion to gather for the kill and to slice off parts of Turkey - its territory or its economy.

Ilhan Kesici, an MP, described the "comeback," the leap forward of the Turkish economy:

By the 1980s, the state seemed to be breaking down. There were queues, even for olive oil, something in which we normally ought to be able to bathe babies. Foreign exchange transactions were a nightmare for the economic bureaucracy. Now these days are gone ... In 1922, if you wanted a table with non-wobbly legs, you had to ask a Greek carpenter. Now there is a Turkish tile factory in Wales, our banks are well represented in Germany, and we are having $[s i c]$ to farm out production of television sets and even fighter aircraft to Poland, Slovakia, and Egypt. I do not believe that Turks have made an appearance of this sort on the European stage since the early 17 th Century. We are, in other words, coming back. ${ }^{67}$

In spite of the above rosy information, some deep and basic drawbacks badly affect the chances of Turkey being able to enjoy a stable economy. Financing a huge chronic gap between Turkey's exports and imports - 30 billion dollars as against 50 billion in the year 2000 - plus a habitual public sector budget deficit of few additional billions (10 billion dollars in 2000), lead the country's economy into a vicious circle of external and internal debts, amazing amounts of interest payments, and greatly contribute to the country's three-digit inflation. The latest UN Human Development Index ranks Turkey as a whole as seventyfourth among the countries of the world, with a point value of 0.778 on a scale of zero to one. ${ }^{68}$

The country's rate of inflation in the mid-1990s was 97 percent, and the average rate in the past decade was 73.7 percent - by far the highest among the forty largest economies in the world. The Turkish economy grew in real terms 3.6 percent on average for the past twenty-five years and, accordingly, the per capita income should have been 6,000 dollars - twice the current figure - had there been less than 10 percent inflation in that period. On average, inflation robbed Turks of 30 percent of their purchasing power despite nominal increases in income. One thousand TL in 1990 was worth TL60 in buying power in 1995, TL18 in 1997, less than TL1 in 2000. Persisting inflation at the current rate means that TL100 of 1990 was only worth TL3 at the end of the year 2000. ${ }^{69}$ Turkey's inflation dates back to the 1970s, to the extreme increases in oil prices. Political priorities, loss-making public banks, a heavily subsidized agricultural sector, a bankrupt social security system, poor and corrupt tax collecting system - all forced the government to borrow money to meet obligations. This heavily fueled inflation, kept interest rate high, and led to ever more expensive borrowing. 
The good signs of 1999 vanished in 2000. The general elections of April 1999 produced a solid coalition government, inflation dropped to 64.7 percent thus approaching the 50 percent mark for the first time since the 1980s, and interest rates tumbled by nearly two-thirds to just over 30 percent. All, however, remained signs and vanished in 2000 and in early 2001. The 1999 sharp drop in tourism - for fear of PKK avenging the capture of Abdullah Ocalan - and the devastating earthquakes, among other things, resulted in a growth rate of minus 6.4 percent, and eventually this turned into the worst year since the early $1940 \mathrm{~s}^{70}$ But the crisis continued and dramatically worsened in 2000 and 2001. In 2001 alone Turkey's GDP dropped by 8 percent. The "reassuring" words of Alan Makovsky, who is highly conversant with Turkey's realities, is indicative of the country's economic chaos: "The situation has now calmed somewhat: the stock market has crept back a bit and interest rates are just barely above 100 percent." ${ }^{71}$ Just few months earlier the interbank interest for December 2000 soared from 400 percent to 1,700 percent. For a time this passed 7,000 percent, later "calmed down," and settled at 3,000 percent. The Istanbul share market dropped by 50 percent compare with January 2000. Foreign currency reserves that on average stood at 22 billion dollars, dropped to 18 billion. Twelve banks collapsed and were taken over by the government and the central bank was forced to remove the Turkish lira's peg to the US dollar. In May 2001 a single US dollar was equal to TL1.35 million. The exchange rate was TL675,000 to the dollar in February 2001, and TL450,000 to the dollar in June 1999. Spiraling inflation resumed and at the end of 2001 Turkey again faced three-digit inflation. Unemployment in various places soared to 15 percent, though the 2001 national figure was expected to be 6.9 percent. Turkey's GDP growth in the years 2000 to 2002 declined by 7.1 percent and GNP per capita dropped sharply to 2,160 dollar (from 2,967 in 2001) - the lowest since 1994. Social, political and international implications of the crisis have been enormous: the gap between Turkey's situation and the standards required for it to join the EU widened. Prices of basic goods and commodities sky-rocketed, employers stopped salary payments owing to lack of money, the purchasing power of salaries and pensions that were paid were cut by half owing to soaring prices. People were fearful lest the military would take power, incidentally giving the coup de grace to Turkey's EU dream. ${ }^{72}$

Hopes, it should be recalled, were high. Just months before the crisis described above, the government promised to bring down the rate of consumer price rises to 25 percent by the end of the 2000, and to get down to single-digit increases by the end of 2002. Similarly, Turkey's central bank decided not to allow a higher than 0.9 percent per month devaluation of the Turkish lira, thus raised expectations that by the end of 2000 Turkey would achieve a 20 percent inflation rate. Six zeroes would then be removed from the Turkish lira exchange rate, so it will equal it to 1 US dollar or to 2 euros. Unfortunately, by the end of 2002 the lira is likely to be close to 2 million per dollar. Spiraling devaluation led to a loss of confidence in the Turkish currency, giving it bad names - "funny 
money" and "phoney money" - and resulted in the Turkish lira's replacement by the US dollar and the Deutsche Mark. ${ }^{73}$ All the above was a heaven-sent gift for those Europeanists who adamantly preached that Turkey would never be able to keep up with EU standards.

In 1996 Turkey had a trade imbalance of 22 billion dollars, 11 percent of its GDP. In mid-1999 the country had a domestic debt of 37 billion dollars and foreign debt of 101 billion dollars - equivalent to half its GNP. This debt is owed by Turkey to European, American and Japanese banks. The government, who desperately needs cash flow to repay its debts, continues to issue high-interest, short-run, inflation-indexed government bonds. It encourages the local population to purchase these bonds, promising close to 90 percent interest payments. Turkey's debts to its citizens grow accordingly: IMF estimations were that the country's domestic debt would double by early 2001. In addition, the government must create 5 million new jobs, which is another high money-consuming role - the unemployment rate in 1998 was 6.3 percent and reached 7.3 percent in 1999 - to ease unemployment and to boost the economy, in particular in formerly war stricken areas.

The 3 million Turks who look for jobs contribute to the figure of 13.5 million people living in poverty in Turkey. United Nations reports indicate that one in seven Turks - 14 percent of 63 million - live in poverty. In Turkey it means below the daily limit of the equivalent of 1.48 dollars. Others quote a daily limit of 2 dollars, which then puts some 40 percent of the Turks under the poverty line. Not surprisingly, this signals that the country is getting poorer: the 1999 per capita annual income was expected to be 3,200 dollars; in reality it dropped below the 3,000 dollar mark and in 2001-2 plunged to just above 2000 dollars. In addition, Turkey is one of the worst countries with respect to distribution of income. Approximately half the population has to make do with a very small proportion of the GNP - one-fifth of it. "Today, the cost of a meal at an expensive restaurant in Turkey equals the annual income of someone from the lower classes," is the Hurriyet's version of this dangerous Turkish inequality. ${ }^{74}$

In the period from March 1998 to March 1999, poor performance was noted in two main sectors: services and industry. Industrial production declined by 7.6 percent, and the fall in importation of capital goods in early 1999 is a further clear indication of declining industrial production. Agricultural production, which saw a slowdown in 1997 - by all means a good omen in a modern economy - grew by 7.6 percent in 1998. When distribution of GDP by sectors is examined, it becomes evident that the share of agricultural production, which was 15.8 percent in 1997, increased to 17.6 percent in 1998, while the share of industrial production decreased to 19.6 percent in 1998 (having been 21.9 percent in 1997). Forty three percent of the Turkish workforce is employed in agriculture, but this sector contributes only 15 percent of the national income. President Demirel, an enthusiastic supporter of curbing the share of agriculture in Turkey's economy, insisted on not more than a 10 percent rural sector and "on a society with less people, but one that is also stronger." The only way of 
"getting richer" and maintaining domestic peace, according to Demirel, is industrialization with fewer people tilling the land:

Here lies Turkey's most basic problem. This is the root of our income distribution problem. Almost half of the population accounts for one seventh of the gross national product. Other countries have solved this problem not by increasing the share of the agricultural sector but by decreasing rural population. There is no other way. Twenty acres of land, a tractor and a family of eight ... This is Turkey's most serious problem. ${ }^{75}$

Summing-up Turkey's economy in the 1990s and in the new millenium, one clearly notices several major trends. Exports demonstrated rapid growth, an increase of 13.1 percent in 1997, but soon slowed considerably due to the negative developments in external demand, and recorded an increase of only 2.7 percent in 1998. There were similar developments in the country's imports: they fell from 49 billion dollars in 1997, to 46 billion in 1998 - a 5.4 percent decline - due mainly to a shrink in domestic demand but also to a fall in crude oil prices. In ordinary times, exports rise, imports decline, and cheaper energy could indicate a good future. However, the increase in exports was temporary, cheap energy has been a short-lived phenomenon, and the decline in production and the economic recession were better explanations for the decrease in Turkey's imports.

The country's interest rates are among the highest in the world - in 1998 they reached 145 percent. In 2001 interest rates decreased slightly but they are still around the three-digit area, something that bears acute economic and social implications. In addition, none of the six governments that have ruled Turkey since 1994 have succeeded in curbing public spending, reducing agricultural subsidies that drain government funds, and bringing up the retirement age of employees to internationally accepted levels to prevent the financially ailing social security system from breaking down. Nor has there been any effective effort to tax the black market economy, which has a turnover of 80 billion dollars, or even 140 billion according to another estimation, which, as William Hale explains, is enabling Turks to ride out crises which could otherwise be expected to be fatal. ${ }^{76}$

Tourism suffered a sharp decline in 1998 and 1999. The fear of the PKK avenging the capture of Abdullah Ocalan in 1998, and the series of earthquakes that rocked Turkey the following summer, caused many tourists to stay away from Turkey. Hotel occupancy during the 1999 season in Antalya was only 20 percent. Close to 9 million tourists visited Turkey in 1998, with tourism revenues reaching 11.2 billion dollars. Less than 6 million tourists came in 1999, reducing revenues to under 7 billion dollars. The sharp decrease in the country's GNP for 1999 - minus 10 percent, from plus 4 percent in 1998 and minus 6 percent in 1999 - is to be partly attributed to the crisis in tourism. Improvement was achieved in 2000 and the target of more than 10.4 million tourists was reached (11.5 million in 2001), producing an 8 billion dollar industry - almost twice the figures for 1999. More than 2 million Germans who visited Turkey led 
the way, followed by tourists from the UK and Russia. The decline of tourism to Israel as a result of the war with the Palestinians, diverted tourists to Turkey but also to Cyprus and Greece. A tourism revival in 2000 expected to yield an increase - though modest - of 1.5 to 2.5 percent in the Turkish economy, plus an inflation rate of "only" 40 to 50 percents (lower than the 67 percent of 1999). As already noted, the Turkish economic turmoil of winter 2000/2001 - some described it as a catastrophe - and the implications of the global economic slowdown, have pushed the Turkish economy backwards. ${ }^{77}$

The beginning of the new millennium has not brought good news for Turkey's economy. The implications of the country's economic crisis could have a detrimental effect, both internally and on Turkey's international status. Alan Makovsky noticed that the emergence of Turkey as a regional power in recent years has been possible thanks also to a perky economy that has seen sustained growth, with occasional interruptions, over the past two decades. Makovsky also warned that, were the country to face long-term economic collapse, a less confident Turkey might no longer be a regional power, with heavily detrimental implications, for instance to the US perception of Turkey as a forward-moving supporter in a mainly hostile region. ${ }^{78}$ Turkish decision-makers should therefore take care that the transition period towards better economic standards would be short, with minimal painful social implications that usually accompany the remedies to economic crises. Turkey's friends should also contribute their share. An economically and socially weaker Turkey is a much worse option.

\section{Notes}

1 See also Atila Eralp, "Turkey and the European Union in the Post-Cold War Era," in Alan Makovsky and Sabri Sayari (eds), Turkey's New World: Changing Dynamics in Turkish Foreign Policy, Washington, DC, Washington Institute of Near East Policy, 2000, p. 178.

2 Turkish Prime Ministry, Undersecretariat of Foreign Trade, TDN, 10 July 1999.

3 Alan Makovsky, "A Euro-Battered Mr. Yilmaz Coes to Washington," Policywatch, No. 291, 18 December 1997.

4 Eralp, "Turkey and the European Union in the Post-Cold War Era," p. 184.

5 Alan Makovsky, “Turkey: Europe-Bound?," MERIA Turkishlist, Alan Makovsky on EU Candidacy, 22 December 1999.

6 Panteion University, Athens, Institute of International Relations, COSMOS, March-April 1998; Ha'aretz, 22 November 2000; Dogu Ergil, "Identity Crises and Political Instability in Turkey," Journal of International Affairs, Vol. 54, No. 1, Autumn 2000, pp. 43-62, 62.

7 Stephen Kinzer, "Aid Brings Turkish-EU Warming," International Herald Tribune, 30 August 1999; Resat Kasaba and Sibel Bozdogan, “Turkey at a Crossroad," Journal of International Affairs, Vol. 54, No. 1, Autumn 2000, pp. 1-20, 11.

8 Makovsky, "Turkey: Europe-Bound?"

9 Birsan Iskendeoglu, “Turkey vs. the West,” Part 2, TDN, 20 February 1999.

10 Rustu Kazim Yucelen, State Minister responsible for Human Rights, Hurriyet, 10 August 2000.

11 TDN, 29 February 2000; Ha'aretz, 19 November 1999. 
12 Hurriyet, 20 December 1999.

13 Ilahn Kesici, member of the Turkish parliament, TDN, 22 February 1999; Kenneth B. Moss, "Europe, the Mediterranean and the Middle East," MERIA Journal, Vol. 4, No. 1, March 2000.

14 For statistics pertaining to Turkish and EU agriculture see Ha'aretz, 11 July 2002; Nataliya Ulchenko, “Turkey-EU Economic Relations: Problems and Prospects," Turkish Yearbook of International Relations, No. 28, 1998, p. 140.

15 Interview, NATO Headquarters, Brussels, May 2000.

16 Washington Post, 9 April 1995; Ha'aretz, 30 March, 1995; Hurriyet, 23 March 2000; Milliyet, 17 February 2000.

17 Dov Waxman, "In the Arms of Europe," Jerusalem Post, 14 December 1999. On Turkey's corruption and the prospect of EU accession see Zeyno Baran, "Corruption: the Turkish Challenge," Journal of International Affairs, Vol. 54, No. 1, Autumn 2000, pp. 127-146.

18 The Economist, reprinted in Ha'aretz, 10 January 2001; Berdal Aral, "The Case of Free Movement for Workers Between Turkey and the European Union," Turkish Yearbook of International Relations, No. 17, 1997, p. 2; Ursula Sautter, Time, 24 June 2002.

19 Faruk Sen, "Islam in Germany," Part 1, TDN, 4 May 1999; Nicholas Le Quesne, "Islam in Europe," Time, 24 December 2001; Ha'aretz, 8 February 2002.

20 "The Economic Dimensions of Turkish Entrepreneurs in Germany," TDN, 10 July 1999.

21 Roger Cohen, New York Times, reprinted in Ha'aretz, 25 December 2000; Sen, "Islam in Germany," Part 1, TDN, 4 May 1999.

22 The Economist, reprinted in Ha'aretz, 22 October 2001.

23 Ursula Sautter, "Losers in the Language Gap," Time, 30 April 2001.

24 The Economist, reprinted in Ha'aretz, 22 October 2001.

25 Adar Primor, Ha'aretz, 16 July 2001.

26 Ari Movement, Istanbul, Ari Bulletin, No. 6, July 1999, p. 6.

27 Ha'aretz, 19 July 1992, quoting Professor Panayiotis J. Vatikiotis; The Economist, 18 March 1989.

28 Ha'aretz, 19 July 1992, quoting Professor Panyiotis J. Vatikiotis; Ha'aretz, 13 June 2001.

29 Ha'aretz, 19 July 1992, quoting Professor Panayiotis J. Vatikiotis; Ha'aretz, 13 June 2001; Sen, "Islam in Germany," Part 2, TDN, 5 May 1999; "The Economic Dimensions of Turkish Entrepreneurs in Germany," TDN, 10 July 1999; Le Quesne, "Islam in Europe."

30 Arye Kaspi, Ha'aretz, 24 May 2002.

31 Benny Landau, Ha'aretz, 8 February 2002.

32 Ruth Sinai, Ha'aretz, 10 May 2001.

33 Roger Cohen, New York Times, reprinted in Ha'aretz, 25 December 2000; The Economist, reprinted in Ha'aretz, 16 May 2000; 10 January 2001; Ha'aretz, 5 July 2001; Ursula Sautter, Time, 24 June 2002.

34 Ha'aretz, 22 December 1994; Ha'aretz, Thomas Friedman, reprinted from New York Times, 23 May 1995; Sabri Sayari, "Turkey: The Changing European Security Environment and the Gulf Crisis," Contents, Vol. 46, No. 1, Winter 1992, p. 12.

35 The Economist, 20 October 1990; Muharrem Kayhan, Chairman of the Turkish Industrialists' and Businessmen's Association (TUSIAA), Washington, DC, Washington Institute's Policy Forum, 19 November 1997; TDN, 15 December 1997; TDN, 5 May 1999.

36 The Economist, Global Forecast for 1999, quoted in Ha'aretz, 21 December 1998.

37 Oulerika Gouaro, The German Commission for Foreign Affairs, The Economist, reprinted in Ha'aretz, 31 May 2001; Walter A. McDougall, "Turkey and the West," Orbis, Winter 2001, pp. 1-12.

38 The Economist, 24 August 1991; 14 December 1991; Yasemin Soysal, "Workers in Europe: Interactions with the Host Society," in Metin Heper, Ayse Oncu and Heinz Kramer (eds), Turkey and the West: Changing Political and Cultural Identities, London and New York, Tauris, 1993, p. 220; Time, 12 October 1992; Bruce Kuniholm, "Turkey 
and the West," Foreign Affairs, Vol. 70, No. 2, Spring 1991, pp. 41-43; Yoav Karni, Ha'aretz Supplement, 9 August 1991. On the European religious and cultural objections to the Turks residing in Europe see: quotation from Professor Panayiotis J. Vatikiotis, Ha'aretz, 19 July 1992; Ha'aretz, reprinted from New York Times, 19 December 1995; James K. Glassman, Washington Post, 5 May 1998; Sen, “Islam in Germany," Part 2, TDN, 5 May 1999; Roger Cohen, New York Times, reprinted in Ha'aretz, 25 March 2001.

39 Andrew Mango, "Testing Time in Turkey," Center for Strategic and International Studies and the Massachusetts Institute of Technology, Washington Quarterly, Winter 1997; TDN, Turkish Probe, 30 November 1997; TDN, Turkish Probe, 7 December 1997; TDN, 16 April 1999; TDN, 12 July 1999; James Kitfield, “The Turkish Model," National Journal, 1 March 2002; Kasaba and Bozdogan, “Turkey at a Crossroad," pp. 1-20.

40 Le Quesne, "Islam in Europe."

41 Turkish Probe, 30 November 1997.

42 Ha'aretz, reprinted from Der Spiegel, 27 January 1995; Ha'aretz, 8 March, 1996; Iskenderoglu, "Turkey vs. the West." Because of the article he published in Der Spiegel, 10 January 1995, Yasar Kemal was charged under Clause 8 of the anti-terrorism law and given a conditional sentence of twenty-four months in prison. Kemal has published thirty-six novels which have been translated into thirty languages. He is a long-time candidate for the Nobel Prize in Literature. See John Darnton, Ha'aretz, reprinted from New York Times, 17 April 1995.

43 Time, 19 October 1992; 20 November 1995; Ha'aretz, 16 June 1992; 10 July 1995; Der Spiegel, reprinted in Ha'aretz, 30 June 1992; Alon Liel, Turkey in the Middle East: Oil, Islam, and Politics, Boulder, CO, Lynne Reinner, 2001, p. 20.

44 E. Salpeter, Ha'aretz, 17 January 1996, quoting Onur Oymen, the Turkish Undersecretary of State for Foreign Affairs.

45 Henry J. Barkey, “The Struggles of a 'Strong' State," Journal of International Affairs, Vol. 54, No. 1, Autumn 2000, pp. 87-105, 105.

46 "French 'Genocide Bill' Aftershocks Continue to Rock Turkey," Turkish Probe, 7 June 1998.

47 Stephen Knight, New York Times, 28 December 1997; Athens News Agency, Daily News Bulletin, 29 January 1997; TDN, 12 June 1998; Tyler Marshall, Los Angeles Times, 20 December 1997.

48 Ian O. Lesser, "Beyond 'Bridge or Barrier': Turkey's Evolving Security with the West," in Alan Makovski and Sabri Sayari (eds), Turkey's New World: Changing Dynamics in Turkish Foreign Policy, Washington, DC, Washington Institute for Near Eastern Policy, p. 208

49 Eralp, "Turkey and the European Union in the Post-Cold War Era," pp. 175, 180-181.

50 Oktay Eksi, Hurriyet, 21 June 2002.

51 Gareth M. Winrow, Turkey and the Caucasus: Domestic Interests and Security Concerns, London, Royal Institute of International Affairs, 2000, p. 37.

52 See also Gregory R. Copley, "Turkey, so Close to the Promise of Ataturk, Sees its Strategic Options Withering," Defense and Foreign Affairs Strategic Policy, Vol. 27, No. 7, July 1999, p. 5; TDN, 1 June 1999.

53 William Hale, "Economic Issues in Turkish Foreign Policy," in Alan Makovsky and Sabri Sayari (eds), Turkey's New World: Changing Dynamics in Turkish Foreign Policy, Washington, DC, Washington Institute of Near East Policy, 2000, p. 23.

54 Radikal, 28 July 1999.

55 TDN, 25 May 1999; TDN, 30 May 1999,

56 Eleftrotipia (Greek), 20 August 1999; Turkish Prime Ministry, Undersecretariat of Foreign Trade, General Directorate of Economic Research and Assessment, Foreign Trade Indicators, January 2000.

57 Figures and estimations are taken from Turkish Prime Ministry, Undersecretariat of Foreign Trade, General Directorate of Economic Research and Assessment, Foreign Trade Indicators, January 2000. 
58 Andrew Finkel, "Keep the Change ...," Time, 17 July 2000.

59 Asaf Savas Akat, "The Political Economy of Turkish Inflation," Journal of International Affairs, Vol. 54, No. 1, Autumn 2000, pp. 265-282, 265-266.

60 Andrew Mango, "Reflections on the Ataturkist Origins of Turkish Foreign Policy and Domestic Linkages," in Alan Makovsky and Sabri Sayari (eds), Turkey's New World: Changing Dynamics in Turkish Foreign Policy, Washington, DC, Washington Institute of Near East Policy, 2000, p. 15; Ziya Onis, "Neoliberal Globalization and the Democracy Paradox; the Turkish General Elections of 1999," Journal of International Affairs, Vol. 54, No. 1, Autumn 2000, pp. 283-306, 289.

61 Hurriyet, 1 May 2000; TDN, 19 April 1999.

62 TDN, 9 March 1999.

63 TDN, 9 March 1999; Milliyet, 24 April 2000; Alan Makovsky, "Step up U.S. Involvement in Turkish Economic Crisis," Policywatch, No. 521, 1 March 2001; Turkistan Newsletter, Vol. 5, No. 63, 11 April 2001; Hale, "Economic Issues in Turkish Foreign Policy," p. 21.

64 See also Milliyet, 11 July 2000; Hale, "Economic Issues in Turkish Foreign Policy," p. 20.

65 Wall Street Journal, 4 February 2002.

66 Zvi Barel, Ha'aretz, 18 April 2001.

67 Ilhan Kesici, TDN, 22 February 1999.

68 Turkish Probe, 21 February 1999.

69 Andrew Finkel, "Keep the Change ... ;" TDN, 2 December 1997; TDN, 3 December 1997.

70 Akat, "The Political Economy of Turkish Inflation," p. 267.

71 Makovsky, "Step up U.S. Involvement in Turkish Economic Crisis," p. 1 (emphasis added).

72 Maryann Bird, "A Clash, then a Crash," Time, 5 March 2001.

73 Hurriyet, 26 April 2000; Akat, “The Political Economy of Turkish Inflation," p. 289.

74 TDN, 27 April 1999; Hurriyet, 17 February 2000; Mete Tuncay, TDN, 4 March 1999; Zvi Barel, Ha'aretz, 11 July 2001; Zeyno Baran, “Corruption,” pp. 127-146, 143.

75 TDN, 9 March 1999 (emphasis added); TDN, 16 April 1999; For Demirel and Turkey's agriculture see also TDN, 10 March 1999.

76 Hale, "Economic Issues in Turkish Foreign Policy," p. 21.

77 Details taken from James Glassman, Washington Post, 5 May 1998; Cumhuriyet, 2 February 1998; Sabah, 2 February 1998; Hurriyet, 24 September 1999; Hurriyet, 17 February 2000; Hurriyet, 26 April 2000; Hurriyet, 7 August 2000; Milliyet, 13 January 1998; Milliyet, 24 April 2000; TDN, 24 April 1999; TDN, 9 May 1999; TDN, 30 May 1999; TDN, 2 July 1999; TDN, 13 July 1999; TDN, 7 August 1999; The Economist, reprinted in Ha'aretz, 3 March 1997; Hikmet Cetin, Speaker of the Turkish Grand National Assembly, presentation before the Washington Institute's Policy Forum, Washington, DC, 5 May 1998; Ha'aretz, 1 September 1998.

78 Makovsky, "Step up U.S. Involvement in Turkish Economic Crisis." 